Tersedia online di: http://ejournal-balitbang.kkp.go.id/index.php/jra

\title{
PERFORMA PERTUMBUHAN DAN RESPONS IMUN IKAN LELE (Clarias sp.) DENGAN PEMBERIAN PROBIOTIK, PREBIOTIK, DAN SINBIOTIK
}

\author{
lis Sumartini ${ }^{* * *}$, Widanarni* ${ }^{* * \#}$, Munti Yuhana**), dan Ayi Santika*) \\ *) Balai Besar Perikanan Budidaya Air Tawar \\ Jl. Selabintana No. 37, Sukabumi, Jawa Barat 43114 \\ *) Departemen Budidaya Perairan, Fakultas Perikanan dan IImu Kelautan, Institut Pertanian Bogor \\ Jl. Agatis, Kampus Dramaga, Bogor, Jawa Barat 16680
}

(Naskah diterima: 13 Desember 2018; Revisi final: 14 Februari 2019; Disetujui publikasi: 14 Februari 2019)

\begin{abstract}
ABSTRAK
Penerapan sistem budidaya intensif seringkali dihadapkan pada penurunan performa pertumbuhan dan kejadian infeksi penyakit. Upaya untuk meningkatkan status kesehatan ikan agar dapat tumbuh dengan baik dan tahan terhadap serangan penyakit sangat diperlukan. Penelitian ini dilakukan untuk mengevaluasi pengaruh pemberian probiotik Bacillus sp. ND2 dan prebiotik madu terhadap performa pertumbuhan dan respons imun ikan lele (Clarias sp.). Ikan lele dengan bobot awal 20,94 \pm 1,13 g dipelihara pada akuarium volume $60 \mathrm{~L}$ dengan kepadatan 15 ekor per akuarium. Ikan diberi empat jenis pakan yaitu pakan kontrol (+ ) dan (-) (tidak ada penambahan Bacillus sp. ND2 dan madu), probiotik Bacillus sp. ND2 1\% prebiotik madu $0,5 \%$ dan sinbiotik (Bacillus sp. ND2 1\%+ madu 0,5\%. Setelah 45 hari masa pemeliharaan, 10 ekor ikan dari masing-masing akuarium diuji tantang dengan A. hydrophila $10^{7} \mathrm{cfu} \mathrm{mL}^{-1}$ kecuali kontrol (-). Hasil penelitian menunjukkan bahwa ikan yang diberi sinbiotik memiliki nilai laju pertumbuhan harian (LPH) paling tinggi $(3,00 \pm 0,04 \%$ dan nilai feed convertion ratio $(F C R)$ paling rendah $(1,00 \pm 0,01)(P<0,05)$. Aktivitas lisozim $\left(52,59 \pm 2,57 \mathrm{UI} \mathrm{mL}^{-1}\right.$ menit $\left.^{-1}\right)$ dan respiratory burst $(0,61 \pm 0,05)$ menunjukkan nilai yang paling tinggi pada perlakuan sinbiotik $(P<0,05)$. Ekspresi gen IL-1 $\beta$ meningkat pada perlakuan prebiotik $(1,25 \pm 0,10)$ pada hari ke-45. Semua perlakuan menunjukkan peningkatan ekspresi pada hari ke-52 dengan nilai tertinggi pada perlakuan sinbiotik $(5,50 \pm 2,77)$. Perlakuan sinbiotik memiliki sintasan yang paling tinggi $(86,67 \pm$ $5,77 \%$ setelah diuji tantang dengan A. hydrophila. Aplikasi sinbiotik (Bacillus sp. ND2 1\%dan madu 0,5\%, mampu meningkatkan performa pertumbuhan, respons imun, serta resistensi ikan lele terhadap A. hydrophila.
\end{abstract}

\section{KATA KUNCl: A. hydrophila; Bacillus sp. ND2; Clarias sp.; madu; sinbiotik}

ABSTRACT: Growth performance and immune responses of Clarias sp. reared with suplementation of probiotic, prebiotic, and synbiotic. By: lis Sumartini, Widanarni, Munti Yuhana, and Ayi Santika

Intensive aquaculture system is continually challenged with some problems such as a decrease in growth performance and disease infection incidences. A substantial effort is needed to improve fish health status to improve the growth performance and disease resistance of cultured fish. To overcome the problems, a feeding trial was conducted to investigate the effects of dietary Bacillus Sp. ND2 and honey on the growth performance, immune responses, and disease resistance of Clarias sp. Fish with an initial body weight of $20.94 \pm 1.13 \mathrm{~g}$ were fed with four practical diets: control diet (+ ) and (-) (no addition of Bacillus sp. ND2 and honey), probiotic Bacillus sp. ND2 1\% prebiotic honey $0.5 \%$ and synbiotic diets (Bacillus sp. ND2 1\%+ honey $0.5 \%$. After 45 days of feeding experimental period, ten fish per aquarium were challenged with $A$. hydrophila except for control (-). The results showed that fish fed with synbiotic produced the highest specific growth rate (SGR) $(3.00 \pm 0.04 \%$ and had the lowest feed conversion ratio (FCR) (1.00 \pm 0.01 ) which were significantly different from the control $(P<0.05)$. The immune assay showed that fish fed with synbiotic produced the highest lysozymeactivity $(52.59 \pm 2.57 \mathrm{UI} \mathrm{mL}-1$ minute-1), respiratory burst activity $(0.61 \pm$ $0.05)$ which were significantly different from the control groups $(P<0.05)$. The fish IL-1b gene expression was enhanced in prebiotic $(1.25 \pm 0.10)$ treatment at theend of the culture period. All treatments showed the enhancement

\footnotetext{
\# Korespondensi: Departemen Budidaya Perairan,

Fakultas Perikanan dan Ilmu Kelautan, Institut Pertanian Bogor.

Kampus IPB Darmaga, Jl. Agatis, Babakan Dramaga,

Bogor 16680, Indonesia

Tel. + 622518622915

E-mail:widanarni@yahoo.com
} 
of IL-1b gene expression at the end of $A$. hydrophila-challenge test, with the highest value attained by fish treated with synbiotic treatment $(5.50 \pm 2.77)$. Fish fed with synbiotic diet showed the highest survival rate $(86.67 \pm 5.77 \%$ after seven days infected with A. hydrophila. In conclusion, synbiotic treatment (Bacillus Sp. ND2 1\%and honey $0.5 \%$ ) could improve growth performance, immune responses and disease resistance of Clarias sp. against A. hydrophila infection.

KEYWORDS: A. hydrophila; Bacillus sp. ND2; Clarias sp.; honey; synbiotic

\section{PENDAHULUAN}

Penerapan sistem budidaya intensif sering mengalami beberapa kendala seperti menurunnya performa pertumbuhan dan meningkatnya serangan penyakit. Penyakit yang sering menyerang ikan lele adalah motil aeromonad septicaemia (MAS) yang disebabkan oleh bakteri Aeromonas hydrophila. Pengobatan dengan antibiotik saat ini sudah dibatasi bahkan dilarang karena dapat menyebabkan efek residu pada tubuh ikan, resistensi, keracunan, dan dapat memengaruhi lingkungan sekitar (Brogden et al., 2014).

Verschuere et al. (2000) mendefinisikan probiotik sebagai mikroorganisme hidup yang diberikan kepada ikan yang dapat berfungsi untuk memodifikasi komunitas mikroba pada sistem pencernaan ikan, meningkatkan nilai nutrien pakan, meningkatkan respons sistem imunitas pada ikan, dan memperbaiki kualitas lingkungan. Beberapa mikroorganisme yang telah banyak digunakan sebagai probiotik di antaranya bakteri Gram positif, Gram negatif, mikroalga, dan ragi (Akhter et al., 2015).

Prebiotik merupakan bahan pangan yang tidak tercerna yang secara selektif mampu menstimulasi pertumbuhan dan atau aktivitas bakteri pada saluran pencernaan ikan (Gibson \& Roberfroid, 1995). Madu adalah salah satu bahan yang berpotensi untuk dijadikan prebiotik karena mengandung oligosakarida dan polisakarida bobot molekul rendah yang tahan terhadap degradasi oleh enzim ikan dan dapat berfungsi sebagai sumber makanan bagi mikroflora usus (Landry et al., 2016). Madu mengandung fruktooligosakarida (FOS), galakto oligosakarida (GOS), dan inulin yang telah banyak digunakan sebagai prebiotik dan telah terbukti mampu meningkatkan performa pertumbuhan ikan, efisiensi pakan, mikrobiota, serta morfologi usus inang (Song et al., 2014).

Istilah sinbiotik merujuk pada probiotik dan prebiotik yang diaplikasikan secara bersama-sama. Gibson \& Roberfroid, (1995) menyatakan bahwa penggunaan konsep sinbiotik dapat memberikan keuntungan terhadap pertumbuhan ikan melalui efek sinergitas probiotik dan prebiotik. Penelitian Tamamdusturi et al. (2016) membuktikan pemberian sinbiotik Bacillus sp. NP5 dan M OS dapat meningkatkan performa pertumbuhan dan memberikan perlindungan terhadap infeksi $A$. hydrophila pada ikan patin
Pangasianodon hypophthalmus. Penelitian ini bertujuan untuk mengevaluasi pemberian probiotik Bacillus $\mathrm{sp}$. ND2 dan madu terhadap performa pertumbuhan, respons imun dan ketahanan penyakit ikan lele (Clarias sp.) terhadap infeksi A. hydrophila.

\section{BAHAN DAN METODE}

Penelitian dilaksanakan pada bulan Februari-Agustus 2018 bertempat di Balai Besar Perikanan Budidaya Air Tawar (BBPBAT) Sukabumi.

\section{Persiapan Bakteri Uji dan Madu}

Bakteri Bacillus sp. ND2 berasal dari koleksi Balai Riset Perikanan Budidaya Air Tawar dan Penyuluhan Perikanan, Sempur, Bogor. Bacillus sp. ND2 yang telah diberi penanda resistensi terhadap oksitetrasiklin dikultur pada media tripticase soy broth (TSB) mengikuti metode Lusiastuti et al. (2016). Densitas bakteri Bacillus sp. ND2 dihitung dengan metode cawan sebar menggunakan media tripticase soy agar (TSA) yang telah diberi $50 \mu \mathrm{g} \mathrm{mL}^{-1}$ oxytetrasiklin. Sebanyak $1 \mathrm{~mL}$ Bacillus sp. ND2 dengan densitas $10^{10} \mathrm{cfu} \mathrm{mL}^{-1}$ menghasilkan $10^{8} \mathrm{cfu} \mathrm{g}^{-1}$ setelah dicampurkan dengan $100 \mathrm{~g}$ pakan. Madu yang digunakan pada penelitian ini merupakan hasil pembudidaya lebah di Depok, Jawa Barat, yang telah dianalisis kandungan oligosakaridanya berupa inulin $69,0 \mathrm{mg} \mathrm{g}^{-1}$; FOS $390,0 \mathrm{mg} \mathrm{g}^{-1}$; dan GOS 310,0 $\mathrm{mg} \mathrm{g}^{-1}$.

\section{Persiapan Pakan Uji}

Pakan komersil dengan kandungan protein 30\% digunakan pada penelitian ini. Penelitian terdiri atas lima perlakuan dengan tiga ulangan yaitu pakan tanpa penambahan Bacillus sp. ND2 dan madu sebagai pakan kontrol (+ ) dan (-), pakan probiotik ditambahkan Bacillus sp. ND2 1\% pakan prebiotik ditambahkan madu 0,5\% dan pakan sinbiotik ditambahkan Bacillus sp. ND2 $1 \%$ dan madu 0,5\% Pencampuran pakan dengan Bacillussp. ND2 dan madu dilakukan dengan cara disemprot dengan menambahkan putih telur sebagai perekat sebanyak $2 \%$

\section{Pemeliharaan Ikan}

Sebanyak 225 ekor ikan lele Sangkuriang dengan bobot awal 20,94 $\pm 1,13 \mathrm{~g}$ ditempatkan pada 15 buah akuarium yang berukuran $40 \mathrm{~cm} \times 60 \mathrm{~cm} \times 50 \mathrm{~cm}$ volume $60 \mathrm{~L}$ dan diaklimatisasi selama dua minggu. Ikan diberi empat jenis pakan yaitu pakan kontrol (tidak 
ada penambahan Bacillus sp. ND2 dan madu), probiotik Bacillus sp. ND2 1\% prebiotik madu 0,5\% dan sinbiotik (Bacillus sp. ND2 1\%+ madu 0,5\%. Tiap perlakuan dengan tiga ulangan. Ikan uji diberi pakan perlakuan secara at satiation dengan frekuensi tiga kali sehari yaitu pada pukul 07.00 WIB, 12.00 WIB, dan 16.00 WIB selama 45 hari.

\section{Uji Tantang}

Ikan lele diuji tantang dengan bakteri A. hydrophila setelah 45 hari pemeliharaan. Sebanyak 10 ekor ikan lele dari masing-masing perlakuan diinjeksi dengan $0,1 \mathrm{~mL}$ suspensi bakteri A. hydrophila dengan konsentrasi $10^{7} \mathrm{cfu} \mathrm{mL}^{-1}$, kecuali kontrol (-) diinjeksi dengan PBS. Masing-masing perlakuan diulang sebanyak tiga kali. Kematian ikan diamati setiap hari dan uji tantang berlangsung selama tujuh hari.

\section{Performa Pertumbuhan dan Sintasan}

Performa pertumbuhan ikan lele yang diamati meliputi laju pertumbuhan harian (LPH) dan feed conversion ratio (FCR) yang dihitung pada awal dan akhir perlakuan. Sintasan dihitung pada hari ke-45 setelah pemeliharaan dan hari ke-52 atau tujuh hari setelah dilakukan uji tantang.

\section{Pengujian Imunologis}

Aktivitas lisozim diuji pada serum darah ikan lele menggunakan bakteri Micrococcus lysodeicticus dan diukur pada absorbansi $450 \mathrm{~nm}$ pada menit ke-0,5 dan menit ke-4,5 (Ellis, 1990). Satu unit lisozim didefinisikan sebagai jumlah lisozim yang menyebabkan penurunan absorbansi 0,001 $\mathrm{min}^{-1}$.

Aktivitas Respiratory Burst (RB) diuji berdasarkan reduksi Nitrobluetetrazolium (NBT) berdasarkan metode Secombes (1990). Analisis kuantitatif diukur menggunakan microplate reader pada absorbansi 630 $\mathrm{nm}$.

Ekpresi gen imun IL-1 $\beta$ diuji berdasarkan metode Ren et al. (2013). Total RNA diekstraksi menggunakan TriZol Reagent RNA (Invitrogen). Kuantitas dan kemurnian RNA diukur menggunakan spektrofotometer nanodrop (Thermo scientific). Selanjutnya satu $\mu \mathrm{g}$ total RNA ditranskriptase menjadi CDNA dalam $20 \mu \mathrm{L}$ Rever Tra Ace- $\alpha$-RT-PCR kit (TOYOBO, Japan). Sebanyak $2 \mu \mathrm{L}$ CDNA diamplifikasi 40 siklus dengan primer IL-1 $\beta$ dan $\beta$-actin (Tabel 1 ) menggunakan real time PCR pada volume $20 \mu \mathrm{L}$ dengan SYBR Green Sensifast.

Reaksi PCR berlangsung pada awal denaturasi $95^{\circ} \mathrm{C}$ selama tiga menit, dilanjutkan dengan 40 siklus pada suhu denaturasi $95^{\circ} \mathrm{C}$ (20 detik), suhu annealing $60^{\circ} \mathrm{C}$ (30 detik), dan suhu extention $72^{\circ} \mathrm{C}$ (20 detik). Analisis data kelipatan respons imunitas ikan lele dihitung dengan metode $2^{-\Delta \Delta \mathrm{Ct}}$ berdasarkan Livak $\&$ Schmittgent (2001).

Data yang diperoleh ditabulasi dengan program Excel 2013 dan dianalisis dengan uji ANOVA menggunakan SPSS 22. Perbedaan antar perlakuan dianalisis dengan uji lanjut Duncan pada selang kepercayaan $95 \%$

\section{HASIL DAN BAHASAN}

\section{Performa Pertumbuhan}

Hasil pengamatan performa pertumbuhan, laju pertumbuhan harian (LPH), sintasan, dan feed conversion ratio (FCR) disajikan pada Tabel 2. Nilai LPH pada perlakuan sinbiotik lebih tinggi $(3,00 \pm 0,04 \%$ dan berbeda nyata dibandingkan semua perlakuan, diikuti LPH pada perlakuan prebiotik dan probiotik yang juga lebih tinggi bila dibandingkan dengan kontrol. Sintasan setelah 45 hari pemeliharaan menunjukkan hasil yang sama antara perlakuan kontrol, probiotik, prebiotik, dan sinbiotik $(100 \pm 0,00 \%)$. Nilai FCR terbaik terdapat pada perlakuan sinbiotik $(1,00 \pm$ $0,01)$ diikuti prebiotik, probiotik, dan kontrol $(P<0,05)$.

Performa pertumbuhan ikan lele dipengaruhi oleh pemberian probiotik Bacillus sp. ND2 dan madu baik pemberian secara tunggal maupun secara kombinasi. Bacillus sp. ND2 adalah bakteri probiotik yang memiliki sifat lipolitik, proteolitik, dan amilolitik (Lusiastuti et al., 2016). Keberadaan enzim pencernaan ini akan meningkatkan kemampuan ikan untuk mencerna nutrien sehingga pertumbuhan ikan akan meningkat. Hal ini didukung oleh penelitian Lusiastuti et al. (2017) yang menyatakan bahwa pemberian Bacillus sp. ND2 mampu meningkatkan biomassa ikan lele (C. gariepinus).

Penambahan madu pada pakan mampu meningkatkan laju pertumbuhan harian ikan lele. Prebiotik di dalam saluran pencernaan akan difermentasi oleh bakteri probiotik menghasilkan asam lemak rantai pendek dan menjadi sumber karbon bagi bakteri probiotik untuk meningkatkan biomassa bakteri (Huynh et al., 2017). Mahious et al. (2006) menyatakan bahwa FOS mampu menstimulasi pertumbuhan Bacillus sp. pada usus larva turbot. Kandungan FOS, GOS, dan inulin pada madu mampu menjadi sumber nutrien bagi bakteri probiotik di dalam saluran pencernaan sehingga ikan mampu memanfaatkan pakan dengan lebih baik.

LPH paling tinggi pada perlakuan sinbiotik menunjukkan bahwa Bacillus sp. ND2 mampu memanfaatkan prebiotik madu dengan baik untuk 
Tabel 1. Primer pada analisis ekspresi gen IL-1 $\beta$ ikan lele (Clarias sp.) yang diberi probiotik, prebiotik, dan sinbiotik

Table 1. Primer on analysis of catfish IL-1 $\beta$ gene expression fed with probiotic, prebiotic, and synbiotic

\begin{tabular}{lccc}
\hline $\begin{array}{c}\text { Nama gen } \\
\text { Gen names }\end{array}$ & \multicolumn{1}{c}{$\begin{array}{c}\text { Sekuen } \\
\text { Sequence }\end{array}$} & $\begin{array}{c}\text { Ukuran } \\
\text { Length }\end{array}$ & $\begin{array}{c}\text { Referensi } \\
\text { Reference }\end{array}$ \\
\hline Actin & Fd : 3'- GCTACTCCTTCACCACCACAG -5' & 144 bp & Ren et al. (2013) \\
JF957365 & Rs : 3'- CGTCAGGCAGCTCGTAACTC -5' & & \\
IL-1 3 & Fd : 3'- TGCACTGTCACTGACAGCCAA - 5' & 112 bp & Ren et al. (2013) \\
JF957370 & Rs : 3'- ATGTTCAGGTGCACTTTGCGG -5' & & \\
\hline
\end{tabular}

Tabel 2. Laju pertumbuhan harian, sintasan, dan feed conversion ratio ikan lele (Clarias sp.) pada perlakuan probiotik, prebiotik, dan sinbiotik

Table 2. Spesific growth rate, survival rate, and feed conversion ratio of catfish with probiotic, prebiotic, and sinbiotic treatments

\begin{tabular}{lccc}
\hline \multicolumn{1}{c}{$\begin{array}{c}\text { Perlakuan } \\
\text { Treatments }\end{array}$} & $\begin{array}{c}\text { LPH } \\
\text { SGR (\%) }\end{array}$ & $\begin{array}{c}\text { Sintasan } \\
\text { Survival rate (\%) }\end{array}$ & FCR \\
\hline Kontrol (+)/Control (+) & $2.43 \pm 0.08^{\mathrm{a}}$ & $100 \pm 0.00^{\mathrm{a}}$ & $1.20 \pm 0.02^{\mathrm{c}}$ \\
Kontrol (-)/Control (-) & $2.45 \pm 0.14^{\mathrm{a}}$ & $100 \pm 0.00^{\mathrm{a}}$ & $1.22 \pm 0.02^{\mathrm{c}}$ \\
Probiotik (Probiotic) & $2.78 \pm 0.07^{\mathrm{b}}$ & $100 \pm 0.00^{\mathrm{a}}$ & $1.07 \pm 0.03^{\mathrm{b}}$ \\
Prebiotik (Prebiotic) & $2.81 \pm 0.03^{\mathrm{b}}$ & $100 \pm 0.00^{\mathrm{a}}$ & $1.05 \pm 0.01^{\mathrm{b}}$ \\
Sinbiotik (Synbiotic) & $3.00 \pm 0.04^{\mathrm{c}}$ & $100 \pm 0.00^{\mathrm{a}}$ & $1.00 \pm 0.01^{\mathrm{a}}$ \\
\hline
\end{tabular}

Keterangan: Angka-angka pada kolom yang sama dan diikuti oleh huruf yang sama tidak berbeda nyata pada taraf uji 5\% LPH: laju pertumbuhan harian, FCR: feed conversion ratio

Description: Numbers in the same column followed by the same letter are not significantly different at significant level 5\% SGR: spesific growth rate, FCR: feed conversion ratio

menstimulasi pertumbuhan bakteri probiotik di dalam saluran pencernaan ikan. Hal ini juga menunjukkan bahwa bakteri probiotik mampu berkompetisi dengan bakteri lainnya dan mendominasi di dalam saluran pencernaan. Prebiotik oligosakarida terbukti mampu menstimulasi pertumbuhan bakteri Bacillus NP5 pada saluran pencernaan ikan patin (Tamamdusturi et al., 2016).

Nilai FCR menunjukkan hasil yang lebih rendah dan berbeda nyata pada perlakuan probiotik, prebiotik, dan sinbiotik dibandingkan dengan kontrol $(P<0,05)$. $\mathrm{Hal}$ ini diduga karena penambahan Bacillus sp. ND2 dan madu berhasil meningkatkan populasi bakteri baik di dalam saluran pencernaan ikan, sehingga aktivitas enzim pencernaan protease, amilase, dan lipase juga meningkat. Enzim-enzim ini akan berperan dalam metabolisme protein, karbohidrat, dan lemak di dalam tubuh ikan menjadi mikromolekul sehingga lebih mudah dicerna oleh ikan. Peningkatan daya cerna akan berdampak pada peningkatan pertumbuhan dan efisiensi pakan. Keberadaan Bacillus sp. ND2 dan madu di dalam saluran pencernaan ikan telah memberikan sinergi yang positif terhadap performa pertumbuhan dan sintasan ikan lele.

\section{Analisis Imunologis}

Pada Gambar 1 menunjukkan bahwa pemberian Bacillus sp. ND2 dan madu mampu meningkatkan aktivitas lisozim pada perlakuan probiotik $(47,41 \pm$ $3,39 \mathrm{UI} \mathrm{mL}^{-1}$ menit $\left.^{-1}\right)$, prebiotik $(43,70 \pm 2,57 \mathrm{UI} \mathrm{mL}$ ${ }^{1}$ menit-1 $)$, dan sinbiotik $\left(52,59 \pm 2,57 \mathrm{UI} \mathrm{mL}^{-1}\right.$ menit1). Perlakuan kontrol tidak mengalami peningkatan aktivitas lisozim setelah masa pemeliharaan 45 hari.

Lisozim adalah sistem pertahanan pertama pada ikan yang penting dalam melawan serangan mikroba. Lisozim melisiskan dinding sel bakteri Gram positif dan membunuh bakteri Gram negatif setelah komplemen dan enzim lainnya menghancurkan dinding sel terluar bakteri (Saurabh \& Sahoo, 2008). Peningkatan aktivitas lisozim pada perlakuan 


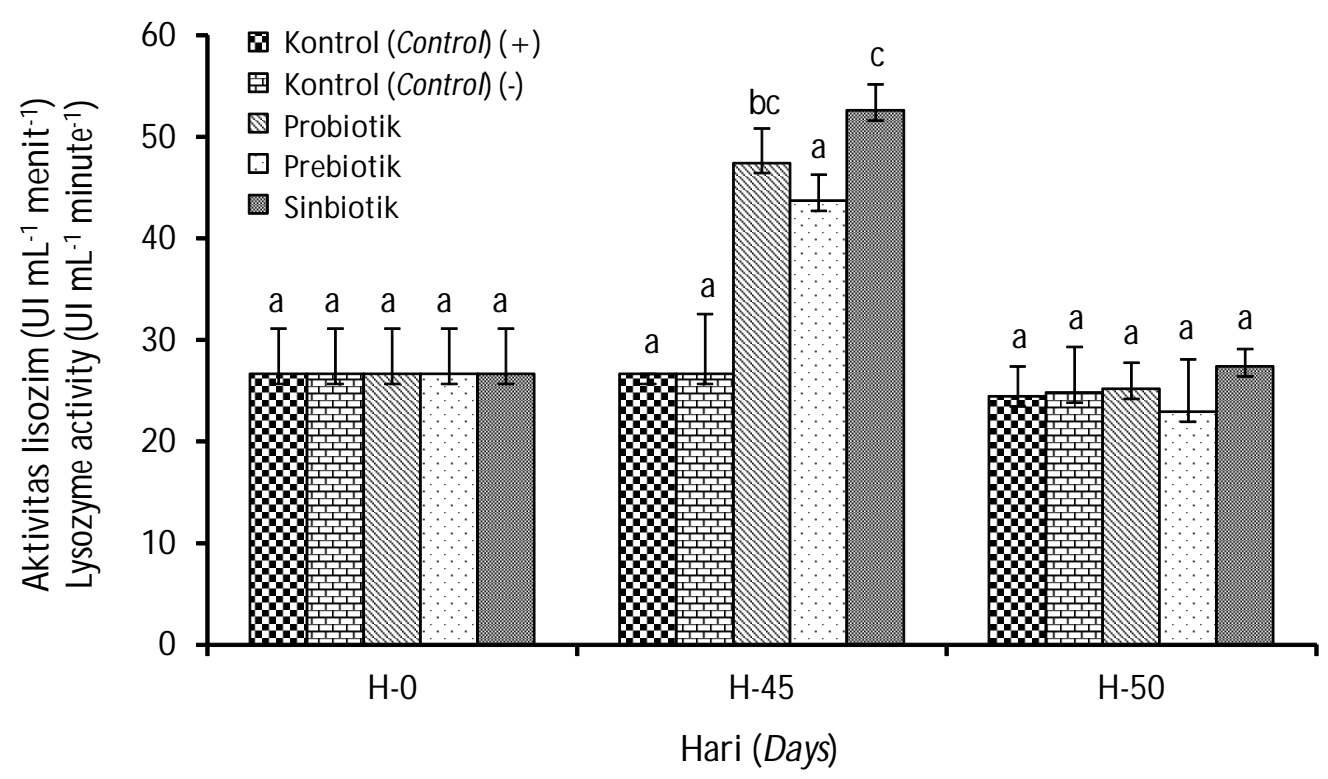

Gambar 1. Nilai aktivitas lisozim ikan lele (Clarias sp.) yang diberi probiotik, prebiotik, dan sinbiotik. Huruf yang berbeda pada periode pengamatan yang sama menunjukkan perbedaan yang signifikan $(P<0,05)$.

Figure 1. Value of lisozyme activity of catfish (Clarias sp.) fed with probiotic, prebiotic, and synbiotic. Different letters on the same monitoring time show significantly difference $(P<0.05)$.

probiotik, prebiotik, dan sinbiotik menunjukkan bahwa telah terjadi interaksi antara Bacillus sp ND2 dan madu dengan sel imun pada ikan lele. Peningkatan aktivitas lisozim juga ditunjukkan pada gibel carp (Mahghani et al., 2014) setelah pemberian sinbiotik.

Penurunan aktivitas lisozim terlihat pada akhir masa uji tantang, dan tidak menunjukkan adanya perbedaan antara perlakuan kontrol, probiotik, prebiotik, dan sinbiotik $(P<0,05)$. Hal ini diduga bahwa ikan telah melakukan pemulihan pascainfeksi dan kembali ke kondisi seimbang. Hasil ini sama dengan penelitian Du et al. (2015) ketika ikan Atlantik salmon diuji tantang dengan $\mathrm{A}$. salmonicida.

Respiratory burst dihasilkan oleh sel fagosit selama proses fagositosis. Proses ini akan menghasilkan reactive oxygen species (ROS) berupa hidrogen peroksida, anion superoksida, dan radikal hidroksil (Song et al., 2014). Penambahan Bacillus sp. ND2 dan madu terbukti mampu meningkatkan aktivitas RB pada perlakuan probiotik $(0,41 \pm 0,05)$; prebiotik $(0,47 \pm 0,02)$; dan sinbiotik $(0,61 \pm 0,05)$ setelah masa pemeliharaan 45 hari $(P<0,05)$ (Gambar 2). Peningkatan respons imun setelah pemberian probiotik dan prebiotik diduga karena adanya efek imunomodulatory dari probiotik dan prebiotik (Akhter et al., 2015) yang akan menstimulir respons imun ikan.
Hasil pengamatan aktivitas RB setelah masa uji tantang menunjukkan telah terjadi penurunan aktivitas bila dibandingkan dengan sebelum uji tantang. Hal ini diduga karena aktivitas fagositosis telah berhasil memusnahkan bakteri patogen A. hydrophila. Ikan selanjutnya masuk pada tahap remodelling jaringan, inflamasi, serta peningkatan sistem imun spesifik (Iwama, 1996).

Sitokin pro-inflamatori IL-1 $\beta$ merupakan salah satu sitokin mediator inflamasi yang merespons infeksi (Carbone et al., 2016). Ekspresi gen IL-1 $\beta$ meningkat pada perlakuan prebiotik, namun tidak terjadi peningkatan ekspresi gen IL-1 $\beta$ pada perlakuan probiotik dan sinbiotik pada akhir masa pemeliharaan. Ekspresi gen IL-1 $\beta$ meningkat pada semua perlakuan tujuh hari pasca uji tantang dengan $\mathrm{A}$. hydrophila dengan peningkatan tertinggi pada perlakuan sinbiotik bila dibandingkan dengan ekspresi gen IL-1 $\beta$ sebelum uji tantang (Tabel 3).

Pemberian probiotik Bacillus sp. ND2 tidak mampu meningkatkan ekspresi gen IL-1 $\beta$ pada akhir masa pemeliharaan. Rendahnya transkripsi gen proinflamatori pada pemberian probiotik Bacillus sp. ND2 diduga karena adanya aksi anti-inflamatori pada spesies probiotik yang diberikan (Zhang et al., 2017) atau dosis yang diberikan kurang optimal (Jessica et 


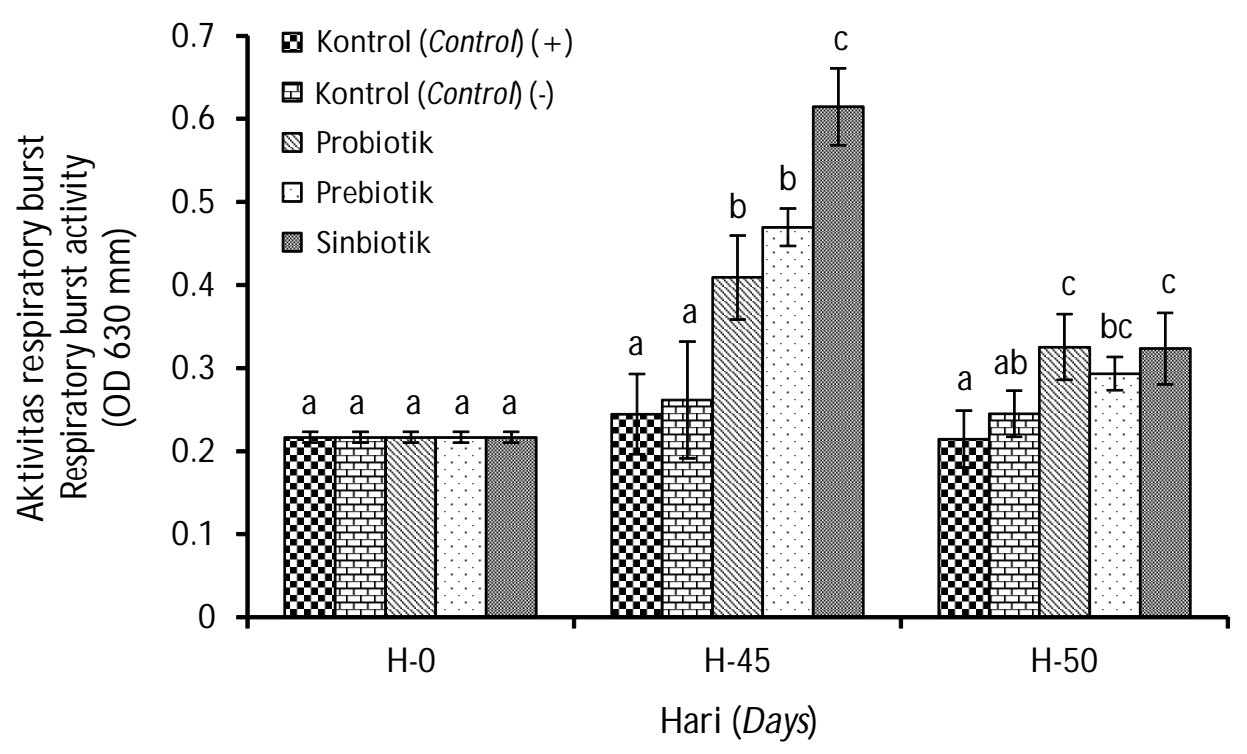

Gambar 2. Nilai aktivitas respiratory burst ikan lele (Clarias sp.) yang diberi probiotik, prebiotik, dan sinbiotik. Huruf yang berbeda pada periode pengamatan yang sama menunjukkan perbedaan yang signifikan $(P<0,05)$.

Figure 2. Respiratory burst activity of catfish (Clarias sp.) fed with probiotic, prebiotic, and synbiotic. Different letters on the same monitoring time show significant difference $(P<0.05)$.

Tabel 3. Tingkat ekspresi gen IL-1 $\beta$ pada ikan lele (Clarias sp.) pada hari ke45 dan hari ke-52

Table 3. Expression of IL-1 $\beta$ of catfish (Clarias sp.) at $45^{\text {th }}$ and $52^{\text {nd }}$ day

\begin{tabular}{lcc}
\hline \multirow{2}{*}{$\begin{array}{c}\text { Perlakuan } \\
\text { Treatments }\end{array}$} & \multicolumn{2}{c}{$\begin{array}{c}\text { Tingkat ekspresi gen IL-1 } \boldsymbol{\beta} \\
\text { Fold change of IL-1 } \boldsymbol{\beta}\end{array}$} \\
\cline { 2 - 3 } & $\mathbf{H - 4 5} \mathbf{( 4 5}^{\text {th }}$ day) & H-52 (52 ${ }^{\text {nd }}$ day) \\
\hline Kontrol (+) (Control (+)) & $1.02 \pm 0.22$ & $1.42 \pm 0.32$ \\
Kontrol (-) (Control (-)) & $1.02 \pm 0.22$ & $1.04 \pm 0.40$ \\
Probiotik (Probiotic) & $0.50 \pm 0.23$ & $1.03 \pm 0.01$ \\
Prebiotik (Prebiotic) & $1.25 \pm 0.10$ & $2.93 \pm 0.78$ \\
Sinbiotik (Synbiotic) & $0.76 \pm 0.38$ & $5.50 \pm 2.77$ \\
\hline
\end{tabular}

al., 2017). Penelitian Jessica et al. (2017) menunjukkan bahwa pemberian prebiotik $\beta$-glukan 0,2\% terbukti mampu meningkatkan sitokin pro-inflamatori TNF$1 \alpha$ dan IL-1 $\beta$. Prebiotik akan berinteraksi dengan PRRs dalam bentuk (MAMPs) berupa asam teichoic, peptidoglikan, protein glikosilat atau polisakarida kapsular bakteri menyebabkan reaksi respons imun (Akhter et al., 2015).

Pada mamalia hampir semua reaksi inflamatori akan diikuti oleh produksi IL-1 $\beta$ dan hal yang sama terjadi pada teleostei. Peningkatan IL-1 $\beta$ terjadi pada ikan rainbow trout yang diinfeksi $A$. hydrophila (Jessica et al., 2017). Hal yang sama terjadi pada penelitian ini bahwa infeksi $A$. hydrophila memicu ekpresi gen IL-1â pada ikan lele. Beberapa faktor seperti spesies bakteri, asal bakteri, dan formulasi, status inflamatori, spesies, dan umur ikan akan memengaruhi hasil pengujian (Picchietti et al., 2008).

Sintasan ikan lele setelah uji tantang dengan $\mathrm{A}$. hydrophila menunjukkan bahwa perlakuan sinbiotik memberikan sintasan tertinggi $(86,67 \pm 5,77 \%)$ $(P<0,05)$. Perlakuan probiotik $(76,67 \pm 5,77 \%)$ dan 


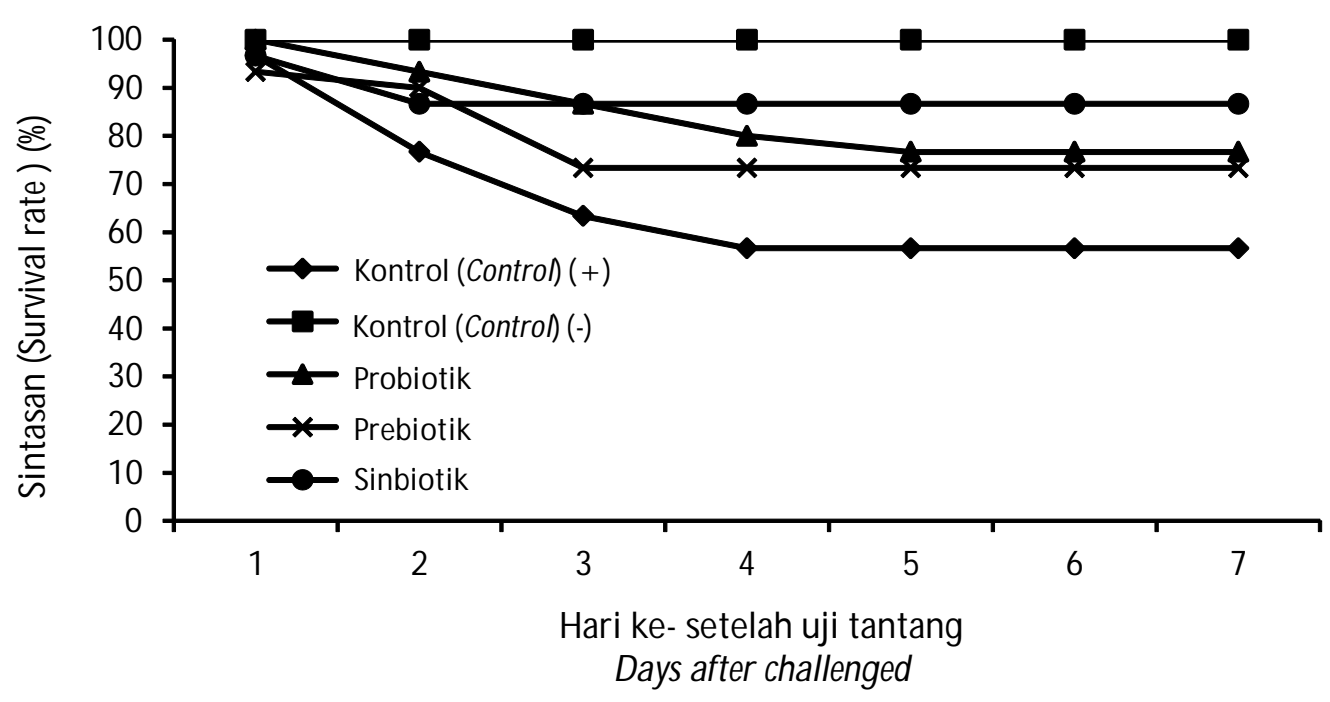

Gambar 3. Sintasan ikan lele (Clarias sp.) setelah uji tantang dengan A. hydrophila. Figure 3. Survival rate of catfish (Clarias sp.) after challenged with $\mathbf{A}$. hydrophila.

prebiotik (73,33 $\pm 5,77 \%$ juga menunjukkan sintasan yang lebih tinggi apabila dibandingkan dengan kontrol $(+)(56,67 \pm 5,77 \%$ (Gambar 3). Hasil yang sama dibuktikan oleh penelitian Tamamdusturi et al. (2016).

Hasil penelitian menunjukkan bahwa kematian mulai terjadi pada 24-48 jam setelah infeksi. Hasil ini sesuai dengan Janda \& Abbot (2010) yang menyatakan bahwa periode inkubasi A. hydrophila 1-2 hari setelah terjadi paparan bakteri. Sintasan yang lebih tinggi pada perlakuan probiotik, prebiotik, dan sinbiotik didukung oleh tingginya kadar lisozim dan respiratory burst pada akhir masa pemeliharaan. Respons imun yang meningkat memberikan pertahanan yang lebih baik pada ikan lele ketika terjadi serangan patogen $A$. hydrohilla.

\section{KESIMPULAN}

Pemberian probiotik Bacillus sp. ND2 1\% dan prebiotik madu 0,5\%(sinbiotik) mampu meningkatkan performa pertumbuhan, respons imun, dan resistensi terhadap infeksi A. hydrophila pada ikan lele (Clarias sp.).

\section{UCAPAN TERIMA KASIH}

Penelitian ini menggunakan biaya dari beasiswa Badan Riset dan Sumber Daya Manusia Kelautan dan Perikanan (BRSDM KP). Penulis menyampaikan terima kasih kepada Balai Riset Perikanan Budidaya Air Tawar dan Penyuluhan Perikanan Sempur, Bogor dan BBPBAT Sukabumi yang telah memfasilitasi selama kegiatan riset ini.

\section{DAFTAR ACUAN}

Akhter, N., Wu, B., Memon, A.M., \& Mohsin, M. (2015). Probiotics and prebiotics associated with aquaculture: A review. Fish and Shellfish Immunology, 45, 733-741.

Brogden, G., Krimmling, T., Adamek, M., Naim, H.Y., Steinhagen, D., \& von Kçckritz-Blickwede, M. (2014). The effect of â-glucan on formation and functionality of neutrofil extracellular traps in carp (Cyprinus carpio L.). Development Comparative Immunology, 44, 280-285.

Carbone, D. \& Faggio, C. (2016). Importance of prebiotics in aquaculture as immunostimulants. Effects on immune system of Sparus aurata and Dicentrarchus labrax. Fish and Shellfish Immunology, 54, 172-178.

Du, Y., Yi, M., Xiao, P., Meng, L., Li, X., Sun, G., \& Liu, $Y$. (2015). The impact of Aeromonas salmonicida infection on innate immune parameters of Atlantic salmon (Salmo salar L.). Fish and shellfish Immunology, 44, 307-315.

Ellis, A.E. (1990). Lysozyme assays. In Techniques in fish immunology. Stolen, J.S., Fletcher, T.C., Anderson, D.P., Robertsen, B.S., \& Van Miswinkel, W.B. (Eds.), SOS Publications, Air Haven, N., p. 101103.

Gibson, G.R. \& Roberfroid, M.B. (1995). Dietary modulation of the human colonic microbiota: introducing the concept of prebiotics. Nutrition, 125 , 1401-1412. 
Huynh, T-G., Shiu, Y-L., Nguyen, T-P., Truong, Q-P., Chen, J-C., \& Liu, C-H. (2017). Current applications, selections, and possible mechanism of actions of synbiotics in improving the growth and health status in aquaculture: A review. Fish and Shellfish Immunology, 64, 367-382.

Iwama, G. (1996). The fish immune system. San Diego, London, Boston, New York, Sydney, Tokyo, Toronto: Academic Press, 68-95, 185-222.

Janda, J.M \& \& Abbot, S.L. (2010). The genus Aeromonas: Taxonomy, pathogenicity and infection. Clinical Microbiology Reviews, 23, 35-73.

Jessica, D., Camino, F-C., Mandiki, S.N.M., Wakson, E., Luis, T., \& Patrick, K. (2017). Dietary â-glucans differentially modulate immune and stress-related gene expression in lymphoid organs from healthy and Aeromonas hydrophila infected rainbow trout (Oncorhynchus mykiss). Fish and shellfish Immunology, 63, 285-296.

Landry, B.K.U., Sahoo, M., Jayabalan, R., \& Francois, Z.N. (2016). Honey, probiotics and prebiotics:review. Research Journal of Pharmaceutical Biological and Chemical Sciences, 7(5), 2428-2438.

Livak, K.J. \& Schmittgent, T.D. (2001). Analysis of relative gene expression data using real time PCR and the $2^{2 \mathrm{DDCt}}$ method. M ethods, 25, 402-408.

Lusiastuti, A.M., Ulkhaq, M.F., Widanarni, \& Pribadi, T.H. (2016). Evaluasi pemberian probiotik Bacillus pada media pemeliharaan terhadap laju pertumbuhan dan perubahan histopatologi ikan lele dumbo (Clarias gariepinus) yang diinfeksi Aeromonas hydrophila. Jurnal Riset Akuakultur, 11(2), 171-179.

Lusiastuti, A.M., Andriyanto, S., \& Samsudin, R. (2017). Efektivitas kombinasi probiotik mikroenkapsulasi melalui pakan untuk pengendalian penyakit M otile Aeromonads Septicemia pada ikan lele, Clarias gariepinus. Jurnal Riset Akuakultur, 12(2), 179-186.

Mahghani, F., Gharaei, A., Ghaffari, M., \& Akrami, R. (2014). Dietary synbiotic improves the growth performance, survival and innate immunity response of Gibel carp (Carassius auratus gibelio) juveniles. International Journal of Aquatic Biology, 2(2), 99-104.

Mahious, A.S., Gatesoupe, F.J., Hervi, M., Metailler, R., \& Ollevier, F. (2006). Effect of dietary inulin and oligosaccharides as prebiotics for weaning turbot, Psetta maxima (Linnaeus, C.1758). Aquaculture International, 14, 219-229.

Picchietti, S., Fausto, A.,M., Randelli, E., Carnevali, O., Taddei, A.,R., Buonocore, F., \& Scapigliati, G. (2008). Early treatment with Lactobacillus delbrueckii strain induces an increase an intestinal T-celss and granulocytes and modulates immune-related genes of larval Dicentrarchus labrax (L.). Fish and Shellfish Immunology, 26, 368-376.

Ren, P., Xu, L., Yang, Y., He, S., Liu, W., Ringø, E., \& Zhou, Z. (2013). Lactobacillus plantarum subsp. plantarum JCM 1149 vs Aeromonas hydrophila NJ-1 in the anterior and posterior intestine of hybrid tilapia Oreochromis niloticus @ \& x Oreochromis aureus $B \&$ : an ex vivo study. Fish and Shellfish Immunology, 35, 146-153.

Saurabh, S. \& Sahoo, P.K. (2008). Lysozyme: an important defence molecule of fish innate immune systems. Aquaculture Research, 39, 223-229.

Secombes, C.J. (1990). Isolation of Salmonid macrophage and analysis of their killing activity. In Stolen, D.P., Fletcher, B.S., Anderson, M.V., \& Winkel, W.B. (Eds.). USA. SOS Publication: Techniques in Fish Immunology, p. 137-152.

Song, S.K., Beck, B.R., Kim, D., Park, J., Kim, J., Kim, H.D., \& Ring $\varnothing$, E. (2014). Prebiotics as immunostimulants in aquaculture: A review. Fish and Shellfish Immunology, 40, 40-48.

Tamamdusturi, R., Widanarni, \& Yuhana, M. (2016). Administration of microencapsulated probiotic Bacillus sp. NP5 and prebiotic mannan oligosaccharide for prevention of Aeromonas hydrophila infection on Pangasianodon hypophthalmus. Journal of Fisheries and Aquatic Science, 11(1), 67-76.

Verschuere, L., Rombaut, G., Sorgeloos, P., \& Verstraete, W. (2000). Probiotic bacteria as biological control agents in aquaculture. Microbiology and Molecular Biology, 64(4), 655-671.

Zhang, C-N., Zhang, J-L., Guan, W-C., Zhang, X-F., Guan, S-H., Zeng, Q-H., Cheng,G-F., \& Cui, W. (2017). Effects of Lactobacillus delbrueckii on immune response, disease resistance against Aeromonas hydrophila, antioxidant capability and growth performance of Cyprinus carpio Huanghe var. Fish and Shellfish Immunology, 68, 84-91. 